\title{
Videotorakoskopska kirurgija pri otrocih
}

\section{Videothoracoscopic surgery in children}

Matevž Srpčič

\section{Izvleček}

Videotorakoskopska kirurgija (angl. video assisted thoracoscopic surgery, VATS) je minimalno invaziven način izvajanja posegov v prsnem košu. Na tak način danes opravljamo skoraj vse posege, ki smo jih nekdaj izvajali "odprto". Prednosti VATS so manjša operacijska rana, manj bolečin, hitrejše okrevanje, krajša hospitalizacija ter dolgoročno boljši funkcionalni in kozmetični rezultat.

$\checkmark$ prispevku podajamo pregled značilnosti videotorakoskopskih posegov v primerjavi z odprtimi posegi, predstavljamo posebnosti pri anesteziji in njihovi tehnični izvedbi ter opisujemo lastne izkušnje.

Posege VATS najpogosteje opravljamo zaradi okužb plevralnega prostora in so danes zamenjali odprte posege. Pomemben del videotorakoskopskih posegov so odstranitve in biopsije pljučnega parenhima zaradi prirojenih anomalij, bolezni pljučnega intersticija, pnevmotoraksa ali malignih bolezni. Biopsija ali resekcija VATS je lahko potrebna zaradi cist ali tumorjev medpljučja. Operiramo tudi prirojene diafragmalne kile ali eventeracije. Operacije na požiralniku so redke, a torakoskopsko povsem izvedljive. Na KO za torakalno kirurgijo UKC Ljubljana izvajamo videotorakoskopske posege pri otrocih od leta 2009. Pri otrocih $v$ starosti od enega dneva do 16 let smo opravili skupno 60 posegov. Operirali smo 8 bolnikov v prvem letu starosti in 36 bolnikov, mlajših od 6 let. Pri večino posegov je pristop VATS danes prva izbira. Otrokom prinaša očitne koristi, zato je $v$ splošnem dobro sprejet. Z napredkom znanja in opremljenosti pričakujemo nadaljnji razvoj.

Ključne besede: VATS, videotorakoskopija, otroška kirurgija, minimalno invazivna kirurgija. 


\section{Uvod}

Posegi, ki jih uvrščamo v področje torakalne kirurgije, predstavljajo med kirurškimi posegi pri otrocih majhen delež. Bolezenske spremembe in stanja v prsnem košu v Sloveniji večinoma operiramo torakalni in srčno-žilni kirurgi.

Večina posegov, ki jih napravimo torakalni kirurgi, je v zadnjih letih del zdravljenja okužb v prsnem košu. Daleč najpogostejša je toaleta plevralnega prostora zaradi parapnevmoničnega empiema. Naslednja večja skupina posegov so biopsije pljuč ali plevre. Tudi primarni ali sekundarni tumorji medpljučja lahko zahtevajo kirurško biopsijo ali odstranitev. Stalen in pomememben delež je kirurgija prirojenih razvojnih anomalij pljuč, cističnih pljučnih malformacij dihalnih poti (angl. cystic pulmonary airway malformations, CPAM) in intralobarnih ali ekstralobarnih sekvestracij. Pri teh so na mestu prave anatomske odstranitve pljučnega parenhima, ki jih včasih opravimo tudi zaradi bronhiektazij ali drugih kroničnih okužb pljuč. Najpogostejši indikaciji za operacijo $v$ prsnem košu takoj po rojstvu sta atrezija požiralnika in prirojena diafragmalna kila. Obe prirojeni anomaliji sta razmeroma redki (2-4 primeri/10.000 živorojenih letno) (1, 2). Atrezijo požiralnika navadno rekonstruiramo skozi desno torakotomijo, prirojeno diafragmalno kilo pa skozi subkostalni rez pod levim rebrnim lokom. Poleg rekonstrukcije atrezije je najpogostejši poseg na požiralniku antirefluksna operacija, ki jo napravimo izključno laparoskopsko. Redke druge bolezni požiralnika, ki jih zdravimo z operacijo, so zapletene kavstične poškodbe, pri katerih moramo požiralnik odstraniti in ga nato tudi nadomestiti.

Vsem posegom v prsnem košu je skupno, da povzročijo razmeroma veliko bolečin in da lahko zapustijo pozne posledice med razvojem prsnega koša, predvsem sinostoze, skolioze, motnje ventilacije in motnje razvoja dojk (3).
Z uporabo manjših torakotomij, pri katerih ne prekinemo velikih mišic prsnega koša, lahko posledice sicer omilimo (4), a je z razvojem minimalno invazivne kirurgije pri odraslih ta zelo hitro postala zanimiva tudi za otroške kirurge (5).

\section{Prednosti minimalno invazivne kirurgije}

Minimalno invazivne operacije $v$ prsnem košu imenujemo torakoskopske operacije. Ker pri večini uporabimo videosistem, se je uveljavila kratica VATS (angl. video assisted thoracoscopic surgery). Prednosti minimalno invazivnih posegov so dokazali v vseh vejah kirurgije. Videotorakoskopski posegi v primerjavi z odprtimi (s torakotomijo ali sternotomijo) povzročijo manjše poškodbe tkiva, manjši vnetni odziv, manjšo potrebo po analgetikih in krajšo hospitalizacijo $(6,7)$. Manj je tudi zapletov (6) in dolgoročnih posledic (8) in večja je preglednost ob dobrem videosistemu in primerni povečavi. Zaradi majhnih serij in težavnosti objektivnega merjenja simptomov pri otrocih je dokazov pri njih sicer manj kot pri odraslih.

\section{Anestezija pri videotorakopskopski kirurgiji}

Osnovna zahteva za videotorakoskopsko kirurgijo je dovolj prostora $v$ plevralni votlini. Tega lahko zagotovijo anesteziologi s selektivnim predihavanjem pljuč, tako da operirano stran popolnoma izključijo ali vsaj predihavajo z manjšimi pritiski. Najmanjši razpoložljivi dvosvetlinski tubusi so široki 9,3 mm (Ch28) in jih pri majhnih otrocih ne moremo uporabljati. Pri njih se poslužimo enostavnega tubusa in pljuča izključimo $z$ blokerjem, ki ga napihnemo $v$ glavnem bronhu na operirani strani. Blokerje lahko upo- rabimo s primerno opremo (fleksibilnim bronhoskopom) in znanjem že pri tubusu velikosti $4,0 \mathrm{~mm}$. Če se pljuča ne izpraznijo dobro, če dober položaj tubusa in blokerja ni mogoč ali če potrebujemo več prostora, si lahko pomagamo z nežnim vpihovanjem ogljikovega dioksida v plevralni prostor. Navadno zadostuje že tlak 4-6 cm $\mathrm{H}_{2} \mathrm{O}$. Insuflacija je zelo uporabna predvsem pri operacijah na preponi in $v$ spodnjem delu medpljučja, a ima tudi pomanjkljivosti, kot je nujnost uporabe zaprtih portov in s tem samo ravnih inštrumentov. Pri dolgotrajnih posegih lahko pride tudi do hiperkarbije $z$ vsemi presnovnimi in hemodinamskimi posledicami (9).

Natančna ocena kardiopulmonalne rezerve, ki je zelo pomembna predvsem pri odraslih, pri otrocih ni ne nujna ne izvedljiva. Sposobnost za enostransko ventilacijo je okrnjena samo pri najbolj prizadetih otrocih z intersticijskimi boleznimi pljuč, pri katerih večinoma izvajamo samo biopsije, medtem ko popolna enostranska ventilacija ni nujna.

\section{Tehnične zahteve za videotorakoskopsko kirurgijo}

Za torakoskopijo potrebujemo video sistem, sestavljen iz optike (vir svetlobe in zajem slike), kamere in stolpa za prikaz slike (ekran), ter možnosti za shranjevanje procesorskih enot in insuflatorja. Večinoma uporabljamo $5 \mathrm{~mm}$ debelo optiko. Število vstopnih točk prilagodimo posegu. Nekatere posege lahko napravimo skozi več ravnih trokarjev (t. i. portov), nekatere pa skozi majhen rez skozi medrebrje (minitorakotomijo) in poljubno število dodatnih portov. Ob insuflaciji uporabimo primerne porte, ki morajo tesniti. Odprti način operiranja brez insuflacije nam sicer nekoliko okrni preglednost, omogoča pa uporabo ukrivljenih inštrumentov, ki so za torakoskopsko kirurgijo zelo priročni. 
$\mathrm{Na}$ voljo so žal samo tisti za odrasle, ki so dovolj majhni za uporabo pri otrocih, saj je jričnih endoskopskih inštrumentov zelo počasen.

Pri VATS kirurgiji odraslih so zelo uporabni endoskopski spenjalniki, ki so za majhne preveliki, saj zahtevajo vsaj $12 \mathrm{~mm}$ širok port in vsaj $45-50 \mathrm{~mm}$ prostora v prsnem košu. Manjši, $5 \mathrm{~mm}$ široki spenjalniki pri nas še niso na voljo. Za varno prekinjanje žil, bronhov in parenhima zato uporabljamo endoskopske sponke in energijske naprave (Ligasure ${ }^{T M}$, Medtronic, in Harmonic AceTM, Ethicon). Kot v splošnem velja za minimalno invazivno kirurgijo je nujna primerna opremljenost, ki jo lahko z iznajdljivostjo nadoknadimo le v majhni meri.

\section{Posebnosti skupin videotorakoskopskih posegov}

\section{Kirurgija plevralnega prostora}

Največ torakoskopskih posegov pri otrocih napravimo zaradi empiema. Pri skoraj polovici bolnikov se ob pljučnici namreč pojavi izliv, ki se pri 5-10\% razvije $v$ empiem $(10,11)$. Preprečimo ga lahko s pravočasno drenažo in intraplevralnim dajanjem fibrinolitikov (tkivnega plazminogen aktivatorja) in deoksiribonukleaze (12). Če kljub temu pride do organizacije plevralnega izliva, je potrebna mehanska odstranitev, ki jo danes v veliki večini primerov napravimo videotorakoskopsko, medtem ko je torakotomija potrebna le pri operacijskih zapletih (predvsem krvavitvah) in pri poznem zapletu empiema, fibrotoraksu, ki pa pri otrocih k sreči nastopi redko. Redko moramo zaradi nekrotizirajoče pljučnice prizadeti del pljuč celo odstraniti, saj se v večini bolezen pozdravi brez trajnih posledic (13).

Mnenja, kdaj moramo empiem razrešiti kirurško, so deljena (14). Kljub v zadnjih letih prevladujočih trendih, ki dajejo prednost drenaži in zdravljenju s fibri- nolitiki, ostaja VATS toaleta poseg, ki omogoča krajšo hospitalizacijo, krajšo potrebo po dihalni podpori in manj dni na intenzivnem oddelku (15).

VATS toaleto empiema pri otrocih izvajamo na KO za torakalno kirurgijo, UKC Ljubljana od leta 2010. Odprte operacije izvajamo le še izjemoma.

Prirojene pljučne anomalije, bolezni pljučnega intersticija in maligne bolezni pljuč

Odstranitve zaradi prirojenih pljučnih anomalij zajemajo vse od pulmektomij do manjših atipičnih resekcij. Vedno stremimo k cilju, da napravimo najmanjšo možno odstranitev in ohranimo čim več parenhima. O prednostih VATS posegov pred odprtimi posegi pri odraslih že dolgo ni več dvoma (16). Pri otrocih je dokazov sicer manj, a tudi pri njih izsledki metaanaliz in retrospektivnih primerjalnih raziskav kažejo, da posegi VATS omogočajo krajšo hospitalizacijo (17-21), manjšo potrebo po analgetikih (21-23) in manj zapletov (18). Največkrat napravimo lobektomijo ali segmentno odstranitev pljuč.

VATS biopsija pljuč ali odstranitev dela pljuč (ponavadi apikalnega), ki pušča in povzroča pnevmotoraks, je manj boleča od odprte. Tudi hospitalizacija je krajša, zato se napotni zdravniki za poseg odločijo prej (24).

Maligne bolezni pljuč so pri otrocih večinoma sekundarne. Indikacije za videotorakoskopske odstranitve so enake kot za odprte posege, a so pri otrocih bolj težavne, ker zasevke težje najdemo in ker nimamo na voljo endoskopskih spenjalnikov.

Na KO za torakalno kirurgijo pri otrocih izvajamo vse pljučne resekcije tudi videotorakoskopsko, v zadnjih letih celo več kot polovico.

\section{Bolezni medpljučja}

Najpogostejše indikacije za posege v medpljučju so razvojne anomalije (bronhogene ali enterogene ciste), nevrogeni tumorji zadnjega medpljučja in večinoma timični tumorji v sprednjem medpljučju. Videotorakoskopsko lahko odstranimo tudi zasevke v medpljučju in napravimo biopsije primarnih ali sekundarnih tumorjev.

\section{Bolezni prepone}

Najpogostejša prirojena motnja prepone je posterolateralna ali Bochdalekova kila (angl. congenital diaphragmatic hernia, CDH) (25). Standardna operacija je repozicija trebušnih organov skozi levi subkostalni rez in direktni šiv prepone. Če je defekt prevelik, moramo prepono rekonstruirati s protezo iz umetnega materiala.

Videotorakoskopsko operacijo CDH so opisali že leta 2001 (26). Kljub težavam s prostorom (operiramo pri novorojenčku v prsnem košu, polnem trebušnih organov) ima tehnika VATS številne prednosti. Pri repoziciji organov pomagata težnost in nežna insuflacija ogljikovega dioksida v prsni koš. Tudi rekonstrukcija posterolateralnega dela defekta je lažja kot pri odprti tehniki.

Omejitve pri pristopu VATS so: prizadet otrok, ki ni sposoben prenesti insuflacije zaradi hemodinamske in respiratorne prizadetosti ter velik defekt prepone, ki zahteva rekonstrukcijo s protezo. Opisujejo tudi torakoskopske rekonstrukcije s protezo, a jih spremlja večja pogostost recidivov kot pri rekonstrukcijah VATS s primarnim šivom (27).

Prednosti posegov VATS posegov sta poleg manjših ran in ohranitve intaktne trebušne stene tudi krajša hospitalizacija in manjša pogostost adhezij v trebuhu, medtem ko pomanjkljivosti vključujejo daljše operacije in večjo pojavnost recidivov (28).

Manj huda motnja razvoja prepone je prirojena eventeracija ali relaksacija. Paradoksno gibanje preprečimo s plikacijo prepone, tj. tehniko, s katero prepono naberemo $v$ gube in jo $s$ tem napnemo. Prednosti VATS plikacije so krajši čas operacije, krajša hospitalizacija in manj zapletov po posegu (29). 


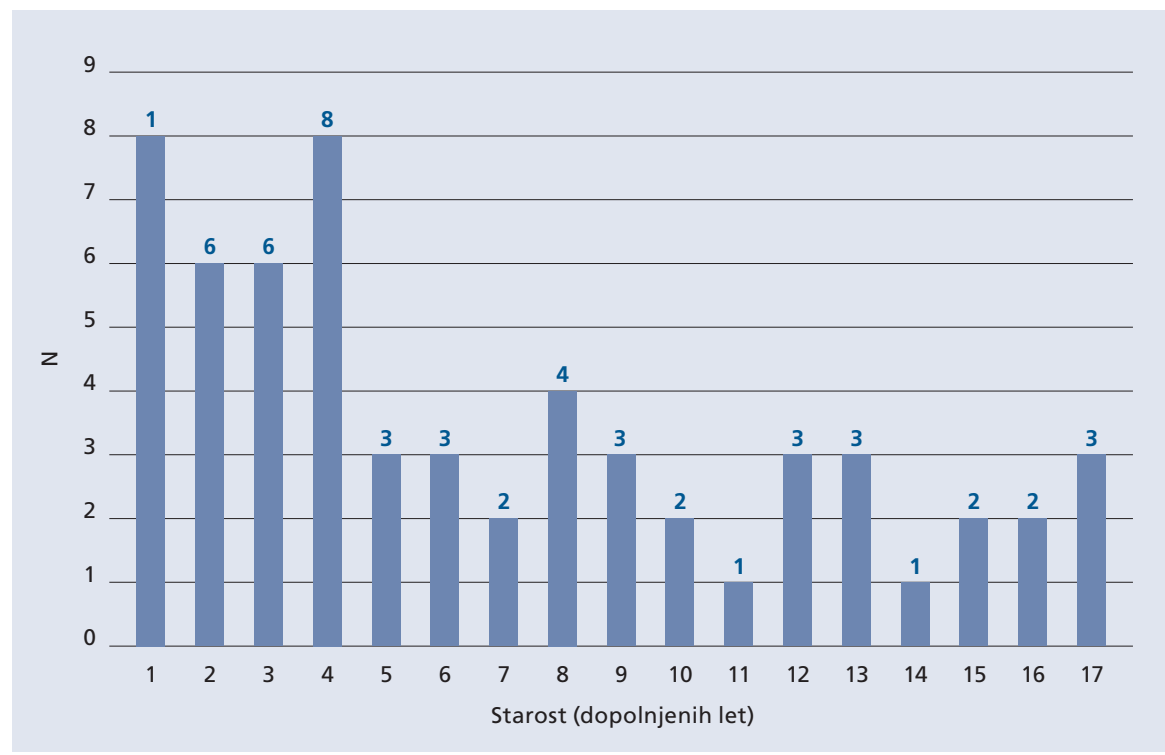

SLIKA 1: ŠTEVILO OPERIRANIH PO STAROSTI (V LETIH).

FIGURE 1: NUMBER OF OPERATED PATIENTS BY AGE IN YEARS.
Povprečna starost [leta] \pm SD; mediana

Spol Ž : M (\%)

TABELA 1: STRUKTURA OPERIRANIH GLEDE NA STAROST IN SPOL.

TABEL 1: DATA ON AGE AND SEX OF OPERATED PATIENTS.
$6,5 \pm 5,5 ; 4,9$ $22(36,7 \%): 38(63,3 \%)$

\begin{tabular}{|c|c|c|}
\hline Skupina posegov & Število [N] & Delež [\%] \\
\hline Empiem & 22 & 36,7 \\
\hline VATS pljuča & 19 & 31,7 \\
\hline Lobektomija & 7 & \\
\hline Segmentektomija & 2 & \\
\hline Ekscizija & 3 & \\
\hline Biopsija & 7 & \\
\hline VATS razno & 9 & 15,0 \\
\hline Biopsija plevre ali medpljučja & 7 & \\
\hline Simpatikotomija & 1 & \\
\hline Izrez zasevkov v medpljučju & 1 & \\
\hline Prepona & 8 & 13,3 \\
\hline Poprava CDH & 4 & \\
\hline Plikacija prepone & 3 & \\
\hline Šiv prepone & 1 & \\
\hline MIE & 2 & 3,3 \\
\hline Skupaj & 60 & 100,0 \\
\hline
\end{tabular}

TABELA 2: PREGLED VIDEOTORAKOSKOPSKIH POSEGOV PO SKUPINAH. TABEL 2: OVERVIEW OF VATS PROCEDURES BY GROUPS.

Legenda: VATS - videoasistirana torakoskopska kirurgija (angl. video assisted thoracoscopic surgery), CDH - prirojena diafragmalna hernija (angl. congenital diaphragmatic hernia); MIE - minimalno invazivna ezofagektomija.
Tudi manj pogosto Morgagnijevo kilo prepone lahko popravimo minimalno invazivno, a laparoskopsko. Naštete posege na KO za torakalno kirurgijo izvajamo od leta 2014, leta 2017 pa smo napravili prvo VATS operacijo prirojene preponske kile pri en dan starem novorojenčku.

\section{Bolezni prebavne cevi}

Najpogostejša prirojena motnja razvija prebavne cevi je atrezija požiralnika (30). Prekinitev ezofagotrahealne fistule in anastomozo za vzpostavitev kontinuitete požiralnika napravimo standardno skozi desno torakotomijo. Videotorakoskopsko operacijo $v$ ta namen so opisali že leta 1999 (31). V specializiranih centrih je tehnika izbire, a jo v splošnem privzemajo počasi. Poseg je med tehnično najbolj zahtevnimi in ga moramo izvesti že v prvih dneh življenja. Prednosti, značilne za videotorakoskopijo, so sicer dokazane (8), a primerjave med novorojenčki, operiranimi $z$ odprto tehniko in tehniko VAS, niso pokazale prepričljivih prednosti pri korekciji atrezije požiralnika (32). Pri nas operacijo zaenkrat izvajamo na "odprt" način.

Najpogostejši kirurški posegi na požiralniku so sicer antirefluksni in izvajamo jih skoraj izključno laparoskopsko (33). Odstranitev požiralnika je pri otrocih k sreči redko potrebna, največkrat zaradi nepopravljivo uničenega požiralnika po kavstični poškodbi $(34,35)$. Pri redkih oblikah atrezije požiralnika primarna rekonstrukcija ni mogoča, zato preostali del požiralnika odstranimo in ga nadomestimo $z$ vezanim presadkom želodca. Tudi za te kompleksne posege so minimalno invazivni pristop (laparoskopijo in videotorakoskopijo) že utemeljili kot uspešno nadomestilo za odprte posege (36). Na KO za torakalno kirurgijo smo že napravili videotorakoskopsko odstranitev kavstično spremenjenega požiralnika ter rekonstrukcijo VATS po t. i. long-gap atreziji požiralnika in rekonstrukcijo z želodcem. 


\section{Pregled izkušenj kliničnega oddelka za torakalno kirurgijo UKC Ljubljana}

V letih 2009-2019 smo na KO za torakalno kirurgijo UKC Ljubljana videotorakoskopsko operirali 60 pediatričnih bolnikov. Prvi VATS poseg smo izvedli 22. 12. 2009, pri katerem smo napravili tudi biopsijo plevre in vstavili plevro-peritonealni šant zaradi sindroma Noonan. Podatke o starosti in spolu operiranih prikazujemo v Tabeli 1, strukturo operiranih po starosti pa na Sliki 1.

Prirojeno preponsko kilo (Bochdalekovo kilo, $C D H$ ) smo doslej operirali pri štirih novorojenčkih, pri dveh prvi dan po rojstvu, pri enem drugi dan po rojstvu in pri enem 23. dan po rojstvu. $\checkmark$ prvem letu življenja smo skupaj operirali 8 bolnikov, v prvih šestih letih pa 36 bolnikov.

Najpogostejša indikacija je bil parapnevmonični empiem, nato operacije pljučnega parenhima, druge biopsije, posegi na preponi in posegi na požiralniku. Pregled posegov podajamo v Tabeli 2.

Perioperativne smrtnosti nismo zaznali in tudi pomembnih perioperativnih zapletov ne. Podatkov o trajanju hospitalizacije še nismo zbrali sistematično. Ugotavljamo, da smo večino operirancev premestili na oddelek in ne v enoto za intenzivno terapijo, odpuščeni pa so bili že prvi dan ali drugi dan po posegu. Izjema so seveda bolniki z empiemom, pri katerih trajanje drenaže in antibiotičnega zdravljenja po posegu narekuje osnovna bolezen.

Splošen vtis vseh strokovnjakov je, da je okrevanje izrazito krajše in lažje, poraba analgetikov manjša in vrnitev $\mathrm{k}$ predhodnim dejavnostim bistveno hitrejša. Dosežemo tudi izjemen kozmetični rezultat, dolgoročnih motenj razvoja prsne stene pa po videotorakoskopskih posegih sploh ne opazimo. Bolj gotova ocena sicer zahteva daljše opazovalno obdobje in bolj sistematičen zajem podatkov.
Zaradi očitnih koristi VATS pri otrocih je zato sprejemanje novega načina operiranja (kljub težavni učni krivulji in vsaj v začetku izrazito višji ravni stresa) pri kirurških, anestezioloških in inštrumentarskih ekipah odlično.

\section{Sklep}

Videotorakoskopska kirurgija je minimalno invaziven način izvedbe posegov v prsnem košu. Na ta način lahko danes opravimo skoraj vse posege, ki smo jih prej izvajali na "odprt" način, torej s torakotomijo ali sternotomijo. Prednosti so manjše operacijske rane, ki operirance tudi manj bolijo, hitrejše okrevanje, krajša hospitalizacija ter dolgoročno boljši funkcionalni in kozmetični rezultati. Ob dobri izvedbi posegov VATS so tudi dolgoročni izidi enakovredni ali celo boljši.

$\mathrm{Na} \mathrm{KO}$ za torakalno kirurgijo UKC Ljubljana izvajamo videotorakoskopske posege od leta 2009. Vse pomembne posege, razen korekcije atrezije požiralnika, smo že izvedli tudi na torakoskopski način. Za večino posegov je VATS danes prva izbira. Otrokom prinaša očitne koristi, zato je kljub večjim tehničnim in organizacijskim zahtevam ter predvsem večji stopnji stresa za vse osebje nov način operiranja dobro sprejet. Z napredkom znanja, pridobivanjem izkušenj in boljšo opremljenostjo pričakujemo še nadaljnji razvoj, izboljšave in inovacije.
Literatura

1. Langham MR, Kays DW, Ledbetter DJ, Frentzen B, Sanford LL, Richards DS. Congenital diaphragmatic hernia. Epidemiology and outcome. Clin Perinatol 1996; 23: 671-88.

2. Sfeir R, Michaud L, Sharma D, Richard F, Gottrand F. National Esophageal Atresia Register. Eur J Pediatr Surg Off J Austrian Assoc Pediatr Surg Al Z Kinderchir 2015; 25: 497-9.

3. Jaureguizar E, Vazquez J, Murcia J, Diez Pardo JA. Morbid musculoskeletal sequelae of thoracotomy for tracheoesophageal fistula. J Pediatr Surg 1985; 20: 511-4

4. Rothenberg SS, Pokorny WJ. Experience with a total muscle-sparing approach for thoracotomies in neonates, infants, and children. J Pediatr Surg 1992; 27: 1157-9; discussion 1159-60.

5. Rogers DA, Philippe PG, Lobe TE, Kay GA, Gilchrist BF, Schropp KP, et al. Thoracoscopy in children: an initial experience with an evolving technique. J Laparoendosc Surg 1992; 2: 7-14.

6. Adams S, Jobson M, Sangnawakij P, Heetun A, Thaventhiran A, Johal $N$, et al. Does thoracoscopy have advantages over open surgery for asymptomatic congenital lung malformations? An analysis of 1626 resections. J Pediatr Surg 2017; 52: 247-51

7. Da M, Peng W, Mo X, Fan M, Wu K, Sun J, et al. Comparison of efficacy between video-assisted thoracoscopic surgery and thoracotomy in children with mediastinal tumors: 6-year experience. Ann Transl Med 2019; 7: 653

8. Lawal TA, Gosemann J-H, Kuebler JF, Glüer S, Ure BM. Thoracoscopy versus thoracotomy improves midterm musculoskeletal status and cosmesis in infants and children. Ann Thorac Surg 2009; 87: 224-8

9. Mukhtar AM, Obayah GM, Elmasry A, Dessouky NM. The therapeutic potential of intraoperative hypercapnia during video-assisted thoracoscopy in pediatric patients. Anesth Analg 2008; 106: $84-8$

10. Hamm H, Light RW. Parapneumonic effusion and empyema. Eur Respir J 1997; 10: 1150-6.

11. Sahn SA. Diagnosis and management of parapneumonic effusions and empyema. Clin Infect Dis Off Publ Infect Dis Soc Am 2007; 45: 1480-6.

12. Piccolo F, Popowicz N, Wong D, Lee YCG Intrapleural tissue plasminogen activator and deoxyribonuclease therapy for pleural infection. J Thorac Dis 2015; 7: 999-1008.

13. Sawicki GS, Lu FL, Valim C, Cleveland RH, Colin AA. Necrotising pneumonia is an increasingly detected complication of pneumonia in children. Eur Respir J 2008; 31: 1285-91.

14. Redden MD, Chin TY, van Driel ML. Surgical versus non-surgical management for pleural empyema. Cochrane Database Syst Rev 2017; 3 : 10651.

15. Derderian SC, Meier M, Partrick DA, Demasellis G, Reiter PD, Annam A, et al. Pediatric empyemas - Has the pendulum swung too far? J Pediatr Surg 2019; 19: 30902-9.

16. Cai Y, Fu X, Xu Q, Sun W, Zhang N. Thoracoscopic lobectomy versus open lobectomy in stage I non-small cell lung cancer: a meta-analysis. Plos One 2013; 8: e82366. 
17. Nasr A, Bass J. Thoracoscopic vs open resection of congenital lung lesions: a meta-analysis. J Pediatr Surg 2012; 47: 857-61.

18. Vu LT, Farmer DL, Nobuhara KK, Miniati D, Lee $\mathrm{H}$. Thoracoscopic versus open resection for congenital cystic adenomatoid malformations of the lung. J Pediatr Surg 2008; 43: 35-9.

19. Bratu I, Laberge J-M, Flageole H, Bouchard S. Foregut duplications: is there an advantage to thoracoscopic resection? J Pediatr Surg 2005; 40: 138-41.

20. Tölg C, Abelin K, Laudenbach V, de Heaulme O, Dorgeret S, Lipsyc ES, et al. Open vs thorascopic surgical management of bronchogenic cysts. Surg Endosc 2005; 19: 77-80.

21. Bonnard A, Malbezin S, Ferkdadji L, Luton D, Aigrain $Y$, de Lagauise P. Pulmonary sequestration children: is the thoracoscopic approach a good option? Surg Endosc 2004; 18: 1364-7.

22. Rahman N, Lakhoo K. Comparison between open and thoracoscopic resection of congenital lung lesions. J Pediatr Surg 2009; 44: 333-6.

23. Diamond IR, Herrera P, Langer JC, Kim PCW. Thoracoscopic versus open resection of congenital lung lesions: a case-matched study. J Pediatr Surg 2007; 42: 1057-61.

24. Butterworth SA, Blair GK, LeBlanc JG, Skarsgard ED. An open and shut case for early VATS treatment of primary spontaneous pneumothorax in children. Can J Surg J Can Chir 2007; 50: $171-4$.

25. Chandrasekharan PK, Rawat M, Madappa R, Rothstein DH, Lakshminrusimha S. Congenital Diaphragmatic hernia - a review. Matern Health Neonatol Perinatol [Internet] 2017; 3.

26. Becmeur F, Jamali RR, Moog R, Keller L, Christmann D, Donato L, et al. Thoracoscopic treatment for delayed presentation of congenital diaphragmatic hernia in the infant. A report of three cases. Surg Endosc 2001; 15: 1163-6.
27. Chan E, Wayne C, Nasr A. Minimally invasive versus open repair of Bochdalek hernia: a meta -analysis. J Pediatr Surg 2014; 49: 694-9.

28. Putnam LR, Tsao K, Lally KP, Blakely ML, Jancelewicz T, Lally PA et al. Minimally Invasive vs

Open Congenital Diaphragmatic Hernia Repair: Is There a Superior Approach? J Am Coll Surg 2017; 224: 416-22

29. Kozlov Y, Novozhilov $V$. Thoracoscopic plication of the diaphragm in infants in the first 3 months of life. J Laparoendosc Adv Surg Tech A 2015; 25: 342-7.

30. Hryhorczuk AL, Lee EY, Eisenberg RL. Esophageal abnormalities in pediatric patients. AJR Am J Roentgenol 2013; 201: 519-32.

31. Lobe TE, Rothenberg S, Waldschmidt J, Stroedter L. Thoracoscopic Repair of Esophageal Atresia in an Infant: A Surgical First. Pediatr Endosurgery Innov Tech 1999; 3: 141-8.

32. Borruto FA, Impellizzeri P, Montalto AS, Antonuccio P, Santacaterina E, Scalfari G, et al. Thoracoscopy versus thoracotomy for esophageal atresia and tracheoesophageal fistula repair: review of the literature and meta-analysis. Eur J Pediatr Surg Off J Austrian Assoc Pediatr Surg Al Z Kinderchir 2012; 22: 415-9.

33. Rothenberg SS. Two decades of experience with laparoscopic nissen fundoplication in infants and children: a critical evaluation of indications, technique, and results. J Laparoendosc Adv Surg Tech A 2013; 23: 791-4.

34. Nwomeh BC, Luketich JD, Kane TD. Minimally invasive esophagectomy for caustic esophageal stricture in children. J Pediatr Surg 2004; 39: 1-6. 35. Cvajnar U, Srpčič M, Homan M. Kavstične poškodbe požiralnika pri otrocih. Slovenska pediatrija 2019; 26: 270-5

36. Garrett D, Anselmo D, Ford H, Ndiforchu F Nguyen N. Minimally invasive esophagectomy and gastric pull-up in children. Pediatr Surg Int 2011; 27: 737-42.
Matevž Srpčič, dr. med. (kontaktna oseba / contact person) Klinični oddelek za torakalno kirurgijo SPS Kirurška klinika Univerzitetni klinični center Ljubljana Zaloška 7, 1000 Ljubljana, Slovenija e-naslov: matevz.srpcic@gmail.com

prispelo / received: 25. 3. 2020 sprejeto / accepted: 16. 4. 2020

Srpčič M. Videotorakoskopska kirurgija pri otrocih. Slov Pediatr 2020; 27(2): 66-71. https://doi. org/10.38031/ slovpediatr-2020-2-03 